\title{
Beware of a pulsating oropharynx
}

Ajay M Bhandarkar, ${ }^{1}$ Ramya Nayak, ${ }^{2}$ Nithyanand Chidambaranathan, ${ }^{1}$ Divya Gopinath ${ }^{1}$

${ }^{1}$ Department of

Otolaryngology-Head and Neck Surgery, Kasturba Medical College, Manipal University, Manipal, Karnataka, India ${ }^{2}$ Department of Pediatrics, Melaka Manipal Medical College, Manipal University, Manipal, Karnataka, India

\section{Correspondence to} Dr Ajay M Bhandarkar, bm.ajay@gmail.com

Accepted 11 November 2014
CrossMark

To cite: Bhandarkar AM, Nayak R,

Chidambaranathan N, et al. BMJ Case Rep Published online: [please include Day Month Year] doi:10.1136/ bcr-2014-208184

\section{DESCRIPTION}

A 45-year-old non-hypertensive woman presented with a foreign body sensation in the throat of 3 months duration. Endoscopic examination showed a pulsating swelling in the right oropharynx with intact oropharyngeal mucosa (video 1). Contrast-enhanced CT (CECT) revealed an aberrant medial course of the right internal carotid artery (ICA) $2 \mathrm{~cm}$ long in the lateral pharyngeal space with $3 \mathrm{~mm}$ of interspersed soft tissue between ICA and oropharyngeal mucosa (figures 1 and 2).

ICA after bifurcation from the common carotid artery extends to the skull base without branching in the neck. ${ }^{12}$ It lies posterolateral to the tonsillar fossa approximately $2.5 \mathrm{~cm}$ from the mucosal surface. ${ }^{2}$ Aberrant ICA is an uncommon variant that accounts for $5 \%$ of incidental occurrences in the neck. ${ }^{1}$ It has been classified based on its ectopic position or presence of neoplasms. ${ }^{3}$ The ectopic variation is commonly seen in the temporal bone and is either tortuous or kinking. A sharp bend denotes kinking whereas curving, elongation, undulation and redundancy denote tortuosity. ${ }^{2}{ }^{3}$ Aberrant ICA develops either as a congenital deformity or due to degenerative vessel wall changes such as hypertension, fibromuscular dysplasia and atherosclerosis. ${ }^{2}{ }^{3}$ Patients may be asymptomatic or may present with a foreign body sensation in the throat, dysphagia or change of voice. $^{2}{ }^{3}$ CECT, contrast MRI or angiography are gold standards in diagnosis. ${ }^{3}$

Aberrant ICA can be misdiagnosed as an abscess or a tumour, the manipulation of which can result

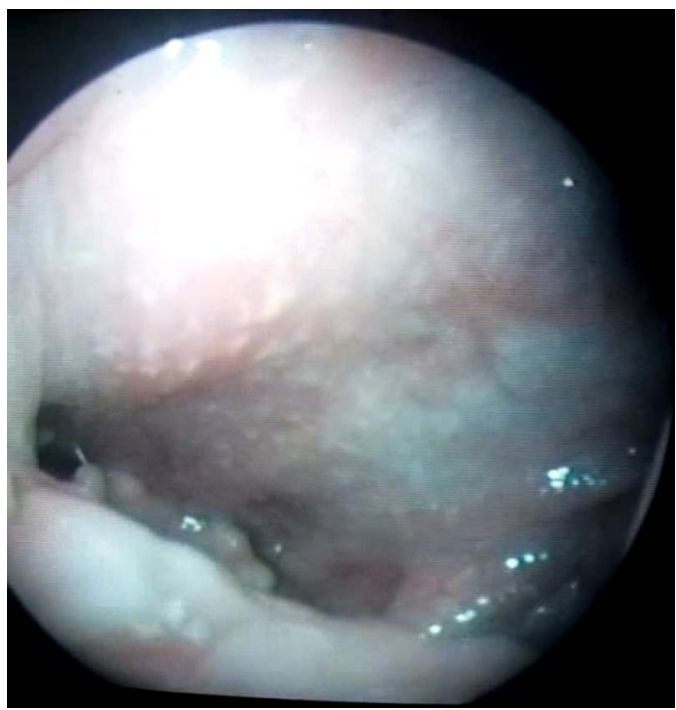

Video 1 Endoscopic video demonstrating a pulsatile mass in the right oropharyngeal wall synchronous with heart pulsations.

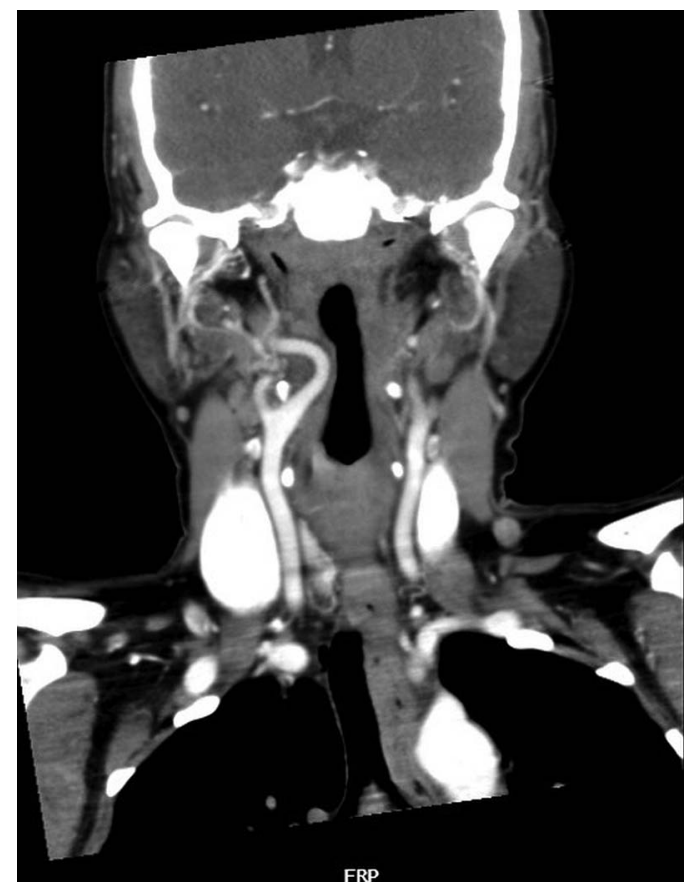

Figure 1 Coronal contrast-enhanced CT of the neck showing an aberrant medial course of the right internal carotid artery $2 \mathrm{~cm}$ long in the lateral pharyngeal space.

in torrential uncontrolled haemorrhage. Hence it is absolutely essential for clinicians to be aware of this rare but important clinical variation of ICA.

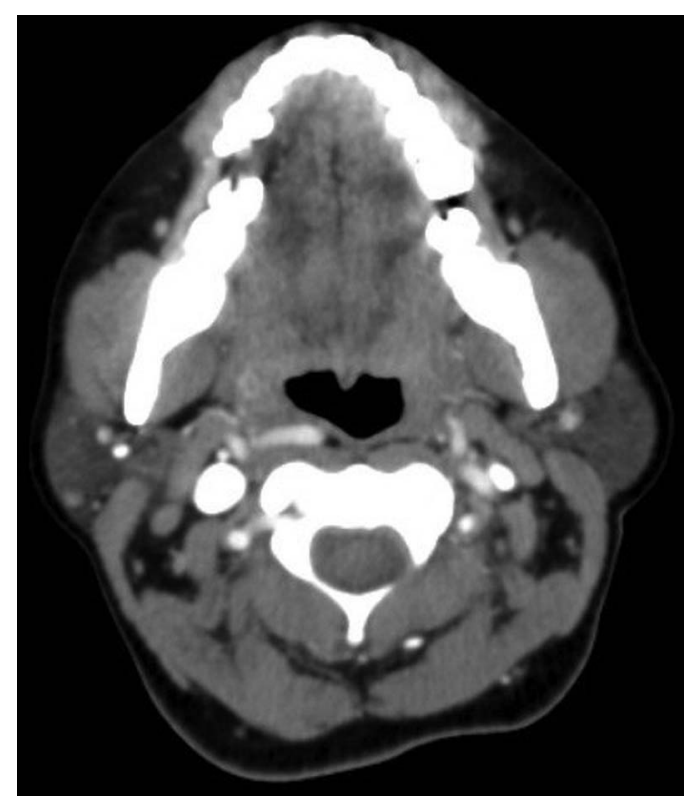

Figure 2 Axial contrast-enhanced CT of the neck showing aberrant internal carotid artery in proximity to the oropharyngeal wall with $3 \mathrm{~mm}$ of interspersed soft tissue. 


\section{Learning points}

- Aberrant internal carotid artery (ICA) can be due to congenital malformation or degenerative changes in the vessel wall.

- Contrast MRI and contrast-enhanced CT or angiography form the gold standard in diagnosis.

- Aberrant ICA can be misdiagnosed as an abscess or tumour in the oropharynx, manipulation of which can cause life-threatening haemorrhage.

Acknowledgements The authors thank Dr Dipak Ranjan Nayak and Dr Balakrishnan for their constant support.
Contributors $A M B$ was responsible for preparing the manuscript. RN collected the literature. NC collected the case data. DG collected the multimedia files and images.

Competing interests None.

Patient consent Obtained.

Provenance and peer review Not commissioned; externally peer reviewed.

\section{REFERENCES}

1 Srinivasan S, Ali SZ, Chwan LT. Aberrant retropharyngeal (submucosal) internal carotid artery: an underdiagnosed, clinically significant variant. Surg Radiol Anat 2013:35:449-50.

2 Pfeiffer J, Ridder GJ. A clinical classification system for aberrant internal carotid arteries. Laryngoscope 2008;118:1931-6.

3 Prokopakis EP, Bouralias CA, Bizaki AJ, et al. Ectopic internal carotid artery presenting as an oropharyngeal mass. Head Face Med 2008;4:20.

Copyright 2014 BMJ Publishing Group. All rights reserved. For permission to reuse any of this content visit http://group.bmj.com/group/rights-licensing/permissions.

BMJ Case Report Fellows may re-use this article for personal use and teaching without any further permission.

Become a Fellow of BMJ Case Reports today and you can:

- Submit as many cases as you like

- Enjoy fast sympathetic peer review and rapid publication of accepted articles

- Access all the published articles

- Re-use any of the published material for personal use and teaching without further permission

For information on Institutional Fellowships contact consortiasales@bmjgroup.com

Visit casereports.bmj.com for more articles like this and to become a Fellow 